\title{
Foreign Experience of Ensuring the Financial Autonomy of Local Self-Governments
}

\author{
Dmytriy V. Nekhaichuk \\ Crimean Business Institute \\ Simferopol, Crimea, Russia \\ dimchikn@mail.ru
}

\author{
Viktoria V. Trofimova \\ Crimean Business Institute \\ Simferopol, Crimea, Russia \\ businesscrimea@mail.ru
}

\author{
Yulia S. Nekhaychuk \\ V.I. Vernadskiy Crimean Federal University \\ Simferopol, Crimea, Russia \\ elekobec@mail.ru
}

\begin{abstract}
The article considers the issues of financial autonomy of local self-governments in foreign countries. It studies the main patterns of the state budget system organization. The work investigates the principles and the structure of the local budgets formation and the role of tax revenues in this process. The research shows the importance of determining the criteria for the financial equalization of the socio-economic state of the territories and creating an effective system of stimulating local authorities.
\end{abstract}

Keywords - local self-government, financial autonomy, local finance, administrative-territorial units, taxation, local budgets

\section{INTRODUCTION}

The local government sector is not able to meet the needs of citizens effectively without the organization of the financial security system that would support the quality production of local goods; therefore the issue of the effectiveness of the financial security system of local self-government is a complex problem, and each of the determinants that influence this process on macro- and micro-levels, can not be considered separately.

The effectiveness of the financial security system of local self-government is considered from the point of view of quality production and providing the citizens with the local services. To ensure the appropriate level and quality of local goods is possible through taking into consideration the following factors as a complex:

1) institutional conditions;

2) the appropriate level of demand parameters for the local public goods;

3) factor terms;

4) financial policy of the state and local self-governments (fiscal decentralization, rationalization of expenditures, maximization of local government budgets revenues, financial equalization) [2].

There are also other factors that affect the successful development of local finance in the context of improving the satisfaction of the citizens' needs for goods and services at the local level. Among these factors, two groups can be distinguished: the parameters of the production factors of local goods and the parameters of the demand for local goods.

It should be noted that the main factors influencing the development of the financial security system of local selfgovernment are the complex of organizational and institutional conditions that ensure the operation of local finance in a certain country. In this connection, the policy of fiscal decentralization plays a particular role.

For the effective development of the financial security system of local self-government, it is necessary for the private sector to cooperate with the local authorities that are closer to both local factors of production and consumers of local goods and that better understand the consumers' needs and can respond more quickly to the changes [1].

Furthermore, to improve the financial security system of local self-government and use the financial and other resources more effectively it is important to ensure a clear single-minded operation of local self-government.

Thus, the main objective of local authorities' activities, in terms of providing citizens with local goods, should be the effective use of scarce resources and the development of the latter on the basis of modern technologies.

\section{MATERIALS AND METHODS (MODEL)}

The goal of the article is to study foreign experience in organizing financial autonomy in the context of effective intergovernmental fiscal relations and building a qualitative system of financial support of local self-government. The 
study uses methods of comparative analysis, expert evaluation, monographic and abstract-logical methods.

\section{RESULTS AND DISCUSSION}

The world practice shows that there are three main patterns of the state budget system organization. The budget system pattern adopted in the country is stipulated by the concepts of budgetary federalism and budgetary unitarism.

The pattern of the budget system has to correspond to the type of local self-government adopted in the country.

The first type of local self-government operates in accordance with the principle of "corporate management". Central authorities do not maintain direct control over local authorities. A significant part of the local budget revenues is made up of its own revenues. The similar type of local selfgovernment has developed in the UK. The sources of local budget revenues in the UK are: grants and subsidies, which are transferred by central authorities. The most stable of them is the "secondary subsidy on tax level", provided as a target contribution, which is calculated in accordance with the financial capacity of each local government and the prospective expenditures. In addition, targeted subsidies for housing construction, police, transport allowances and capital disbursements are provided; deductions to local budgets in the form of payment for the land that is not in agricultural maintenance, and real property tax; other revenues - housing rent, payment for the services provided by local authorities. The self-government in the United States of America is close to the British local government; however the bodies of such self-government report directly to local authorities. The distribution of powers between local authorities and local selfgovernment bodies is determined individually for each state by a set of its laws and regulations. The revenues of local budgets and the state budgets are decentralized; the taxation system also varies according to the state; the budgetary process has individual peculiarities [2, c.14-16].

The second type of local self-government is characterized by the fact that local self-government bodies are independent in performing their functions (they are independent institutions of self-government), but at the same time they exercise delegated powers of central authorities. Therefore, local selfgovernment bodies operate as self-governing state institutions that perform the functions of local authorities and exercise delegated powers of central authorities [2, p. 17]. In particular, the Basic Law of Germany stipulates the observance of the principle of coherence of powers and expenditures and the principle of the correspondence of expenses and incomes in the relations between the federation and the lands in the sphere of finance [2, p.88]. Due to the internal relationship between the distribution of powers of federal authorities and land authorities, on the one hand, and the distribution of tax revenues between them, on the other hand, covering the expenses of the federation and the lands to implement the set objectives is ensured by revenues from the sources specified for each level of government. The principle of coherence is the basis of the entire financial system of Germany [3, p. 51]. The budgetary system of Germany consists of the budget of the Federation, the budgets of the lands and communities.
The third type of local self-government is characterized by a high level of administrative control over local authorities by the central authorities. This type of local self-government has been fully implemented in France. At the same time, local authorities have quite broad powers in the sphere of the implementation of the national policy of social and economic development and formulation a local concept of social and economic development [3, p. 18].

The formation of multi-level budgetary systems is stipulated by the need for financial equalization with simultaneous redistribution of authorities between central and local authorities. In its turn, the need for financial equalization results from the need to equalize the socio-economic development of administrative-territorial units [3, p. 16]. This is confirmed by the practical experience of a number of developed countries, such as the United States of America, Spain, Austria, Switzerland, and Sweden, where local budgets have a high level of financial autonomy and are virtually independent of the central administration budget.

The sources of local authorities' financing in most countries of Central and Eastern Europe are their own financial resources of local governments. Consequently, they have a significant financial autonomy in the formation of the local budgets revenues, spending these funds, assessing local tax rates and charges. However, administrative-territorial units, which are at a high level of development, appeal to strengthen the financial autonomy of local government. In this case, such strengthening of the financial autonomy of local authorities will mean a decrease in the effectiveness of equalization of financial opportunities. In post-industrial countries, local authorities have obtained the right, at their discretion and on their own responsibility, to provide public services to the population of the corresponding administrativeterritorial units. Taking this into account, there is a tendency to a gradual increase in financial autonomy of local selfgovernment bodies [4, p. 17]. The basis of the financial autonomy of the local governments of the developed countries is local taxes and local surcharges for the state taxes. The processes of a similar nature occur even in the countries with the engrained centralized power (Russia, Jordan, Morocco, China, Thailand, etc.) [4, p. 143].

One of the quantitative characteristics of the level of financial autonomy of local self-government bodies is the ratio of the share of transfers in local budget revenues, which allows to state the degree of dependence of the local budget on top-level budgets. For unitary states as a whole, this indicator is higher than for federal states.

The amount of transfers provided from the budget to local budgets depends on a large number of factors and it is calculated in accordance with certain approaches. In particular, when calculating the volume of related transfers, we take into consideration the volume of the local budget revenues and the volume of transfers determined in proportion to their value or in such a way as to compensate for the actual expenses of the local budget.

When allocating budget grants, the volume of transfers is determined by a formula method and is planned as a part of the local budget revenues. A significant role is played by 
target transfers, which provide the greatest impact on the change in expenditure programs of local authorities in the desired direction [3, p. 55-58].

It should be noted that the expansion of the financial autonomy of local government bodies through the decentralization of public administration in most countries of Central and Eastern Europe and the Commonwealth of Independent States is much faster than the formation of an adequate financial base. In the structure of sources of financial resources of local authorities of these groups of countries, on the basis of their division into internal and external, the latter significantly exceed, demonstrating the domination of central authority [5, p. 22].

Formation of local budgets at the expense of a part of state taxes can be in different forms, which stipulate different influence of local authorities on tax revenues. Local authorities can: establish their own additional rates (surcharges) for certain taxes; have the right to a certain percentage of tax incomes collected in the relevant territory of administrative-territorial units, or to a legally established share of national tax revenues [5, p. 13].

When creating local budgets at the expense of a part of state taxes, local authorities can not determine the base of taxation and fix the tax rates independently. This is done by the central authorities. Moreover, the level of financial autonomy of local authorities depends on how much they can influence the formation of tax legislation (by definition of standards for inter-budgetary taxes assessment). For example, in Spain and Italy, the central authorities agree with the authorities of administrative-territorial units on the conditions for inter-budgetary taxes assessment.

The access of local governments to state taxes is considered to be necessary when they are responsible for carrying out a wide range of socially important functions (for example, in providing educational and health services) $[5, \mathrm{p}$. 10]. In this case, the expenditures of local budgets concerning the social sphere are financed by fixed incomes [5, p. 75]. A positive characteristics of the system of local budgets formation at the expense of a part of the national taxes is the fact that common taxes and unified management allow for an effective fiscal policy, and the changes in tax revenues and, correspondingly, the risks of such changes are distributed among different types of budgets, that is they affect not only the local, but also the central budget.

Granting to local authorities the right to establish their own additional rates (surcharges) for the national tax, which goes to the central budget, allows them to bring rather flexibly the financial capabilities of local budgets to conformity with the requirements for financing their expenditures. The amount of such surcharges may be limited or established by local authorities at their discretion. A negative characteristic of the use of such a source of local budgets financing is multiple taxation of the same object [5, p. 41].

On average, in the unitary states of Europe (not taking into account post-socialist countries), tax revenues provide about $50 \%$ of local budget revenues, calculated as the sum of tax revenues of local budgets and the received transfers [5, p. 41].
Taxes on which local authorities have the right to fix rates and grant benefits are the most important source of local budgets revenues (they provide an average of about $42 \%$ of their total volume), while targeted transfers amount to $25.8 \%$, nonpurpose transfers $-24,3 \%$, while the state taxes, which are distributed between the central and local budgets, amount to $4.3 \%$. It should also be emphasized that in the last decade the share of tax revenues in local budget revenues in many developed countries has remained fairly stable, while their tax autonomy has expanded.

In post-socialist states, a significant part of local budget revenues is provided by state taxes (for example, their share in the Czech Republic is $51.8 \%$, in Poland - 38.6\%). At the same time, the share of transfers (both targeted and non-purpose) is comparable with the average indicators of unitary states. An important feature of post-socialist countries is the low share in the total revenues of local budgets of those taxes on which local authorities can set rates or grant benefits. So, in Poland, such taxes are about $12 \%$, in France - $48.9 \%$ [4, p. 41]. In some countries, despite the fact that local authorities have the right to change tax rates, virtually the same rates apply to all territories of administrative-territorial units, that is, in practice the right to tax autonomy is not used [4, p. 184].

In most post-socialist countries, the corporate profit tax plays an important role in the formation of local budgets: it accounts for more than $10 \%$ of the tax revenues of local budgets (in the Czech Republic the corresponding figure is $26 \%$ ).

In developed countries there is quite often a ramified system of local taxes and charges, based on the principle of optimal fiscal burden. Whereas the mechanism of tax collection is much different in each country and the principle of taxation optimization is realized both by reducing tax rates and expanding the tax base, and through the system of benefits aimed at achieving specific goals of socio-economic development of administrative-territorial units [5, c. 306].

Local taxation should be commensurable with the state one and it shouldn't create an excessive fiscal burden on local residents. [6, c.49-50]. However, as L. Demidenko believes, [6, c. 22], the higher the country's level of development is, the more significant role local taxes and charges play in local budgets formation. According to a foreign experience, the most important in fiscal value are such local taxes as real estate tax and land tax (fee) [6, c. 307]. In particular, property taxes are high as fiscal value in local budgets in the USA, Ireland, Netherlands, Great Britain, Belgium, Denmark, Germany, Italy, Norway, (70-90\%). The less common are the local excise-duties on tobacco, petrol, and alcohol, local sale and energy sources taxes (Cyprus, Spain, Italy, and Belgium). Quite often, along with the state taxation of personal incomes, corporate incomes and business profits, the local taxes are imposed (North-European countries, Japan) [6, pp. 39-40]. If the laws and regulations of the country allow local authorities to fix the local tax rate within certain limits, then, as a rule, the minimum possible rate is fixed. In some countries the financial competence of local governments relative to taxation is strictly limited (France, Spain). In other countries the centralization precedes tax sharing [7, p. 49]. 


\section{CONCLUSION}

The results of the research allow us to draw the following conclusions.

1. The priority direction of financial autonomy development of local self-government should, first of all, be gaining of the budgetary and tax independence.

2. A clear legislative definition and fixing of local taxes and fees, providing large powers to regulate them will ensure the growth of financial resources of self-government, the implementation of a balanced fiscal policy and the increased level of financial autonomy.

3. The delegation of state powers on financing social protection to local authorities will enable reduction of reciprocal inter-budgetary financial flows and the share of transfer payments in the local budgets revenues.

Regarding the prospects for further research in this direction, it's important to note that they will include the analysis of determining the criteria for financial equalization of the socio-economic condition of the territories and the creation of an effective system of local authorities' stimulation.

4. The practice of tax shares is common in Central, Eastern Europe and the countries of the Commonwealth of Independent States. In the countries of Central and Eastern Europe, the establishment of tax sharing standards for selfgoverning units of the basic (low) level (city, village, settlement) is simpler and more transparent; the tax sharing standards for these administrative-territorial units are determined directly at the national level, while in the countries of the Commonwealth of Independent States another approach dominates: determining the tax sharing standards is conferred to the representative authorities of regional and district levels.

\section{Acknowledgment}

We are grateful to the administration of the Crimean Business Institute represented by the rector Valery Ivanovich Tarasov for financial support of the scientific research of the young scientists and organizational assistance in promoting scientific and practical research results.

\section{References}

[1] Sadkov V.G., Grinkevich L.S. Interbudgetary relations and methodological basis for determining the size of local budgets [Mezhbyudzhetnyie otnosheniya i metodicheskie osnovy opredeleniya razmerov mestnyih byudzhetov]. Finansy. 2012. № 6. p. 16-18.

[2] Nesterenko A.S. Financial independence of local government and its provision. [Finansovaya samostoyatelnost mestnogo samoupravleniya i ee obespechenie]. Tamojennoe delo. 2013. № 6. p. 88-92.

[3] Kliyanenko B., Grechana S. Using the model of German budgetary federalism [Ispolzovanie modeli nemetskogo byudzhetnogo federalizma]. Finansy. 2013. № 6. p. 48-57.

[4] Dulshikov Y.S. Regional policy and management [Regionalnaya politika i upravlenie]. Izdatelstvo RAGS. 2014. 257 p.

[5] Dvoyenosenko S. The problems of decentralization of development management in interaction with financial stability of regions [Problemy detsentralizatsii upravleniya razvitiem vo vzaimodeystvii s finansovoy ustoychivostyu regionov]. Upravlenie sovremennym gorodom. 2004. № 10-12. p. 143-152.

[6] Sluhay S. V. Interbudgetary transfers in post-socialist countries: from theory to realities [Mezhbyudzhetnyie transfertyi v postsotsialisticheskih stranah: ot teorii k realiyam]. Monograph. Kiev.: ArtEk. 2012. 280 p.

[7] Mnyh M. V. The role and importance of local finance in the development of local self-government [Rol i znachenie mestnyih finansov v razvitii mestnogo samoupravleniya]. Ekonomika, Finansyi, Pravo. 2014. № 2. p. 15-17.

[8] Bird R.M. Intergovernmental Fiscal relations: Universal Principles, Local applications. Georgia State University. 2010. WP № 00-2. p. 1013.

[9] Vasyl'yeva N. The role of local taxes and fees in ensuring the financial independence of local governments [Rol mestnyih nalogov i sborov v obespechenii finansovoy nezavisimosti organov mestnogo samoupravleniya]. Upravlenie sovremennym gorodom. 2014. № 1012(16). p. 306-310.

[10] Demydenko L. M. The role of local taxes in the formation of revenues of local government budgets. [Rol mestnyih nalogov $\mathrm{v}$ formirovanii dohodov byudzhetov organov mestnogo samoupravleniya]. Vestnik $\mathrm{KNU}$

T.G. Shevchenko. Sbornik nauchnyih trudov. Vyipusk 70. Kiev. 2012. p. 21-23. Seriya «Ekonomika». 